\title{
Is the Ceiling Truly Glass or Something More Variable?
}

\author{
James F. Guyot
}

Published online: 4 October 2008

(C) The Author(s) 2008. This article is published with open access at Springerlink.com

\begin{abstract}
Women advance more rapidly in the appointive executive and judicial branches than in the elected legislative branch at both national and state levels. Demand side and supply side factors explain much of this. In particular, greater male variability restricts the opportunity for gender equity.
\end{abstract}

Keywords Male variability · National and state levels . Women in politics

"Glass ceiling" seems an apt metaphor for the political architecture where $53 \%$ of the population are eligible but only 16 women join the one-hundred-member elite club that is the Senate of the United States, where one-half of the students enrolled in law schools are women but they comprise only one-fourth of those who ascend to judgeships in the federal courts, where $55 \%$ of the bachelor's degree holders in the country are women but they make up barely $27 \%$ of the Senior Executive Service in the federal civil service. The metaphor is deceptive, however, in describing reality, in explaining how we got to where we are, and in guiding speculation about where things may go in the future.

Glass implies a smooth surface, while the barrier to women's advance in government is uneven, as wavy as a fun-house mirror. It magnifies opportunities in some places and minimizes them in others. Glass is crystalline and must be circumvented or cracked by those who wish to rise. A

J. F. Guyot $(\square)$

Baruch College/CUNY, School of Public Affairs,

One Bernard Baruch Way, Box D-0901, New York,

NY 10010, USA

e-mail: JGuyot@baruch.cuny.edu better metaphor for the advancement of women might be the flow of a fluid of varying viscosity over time and place. Glass can be shattered, clearing the way toward gender parity. Yet, not all possibilities are probable, so we need to assess what may be several intractable restraints along the way. This paper will document the variability, suggest some explanations for the differing viscosities, and speculate about possible intractabilities.

\section{Two Dimensions of Variability}

The progress that women have made to date in scaling the heights of the national government varies on a horizontal dimension across the three branches of the separation of powers in a pattern that is replicated at the state level. It also varies between state and federal levels. Table 1 shows these two dimensions of variation.

Women have clearly progressed less in the elected legislatures at both national and state levels than they have in the appointed portions of the judiciaries or the executive branch. At the federal level they have captured over onequarter of the Senior Executive Service and the Title III judgeships but only one-sixth of the U.S. Congress. At the state level they serve as more than one-quarter of the state agency heads and hold almost three-tenths of the seats on courts of last resort, but fill less than one-quarter of the seats in state legislatures.

This difference in the pace of progress between selection by hierarchical decision and selection by competitive election shows up within the executive branch itself. At the head of the executive branch, both the elected President and Vice-President are male (it may change next year). Women currently enter in significant numbers in the politically appointed cabinet at roughly one-quarter in each 
of the last two presidencies, if one counts only those offices listed as cabinet level in both periods. Further down the hierarchy, in the Senior Executive Service, they are represented more heavily in the politically appointed segment than in the competitively promoted part of that elite staff. Similarly, in the states women are more likely to "circumvent the glass ceiling" in order to become agency heads if the position is filled by gubernatorial appointment.

A second dimension of variation in the apparent ceiling for women in government that is evident in Table 1 is the vertical one, their greater representation in the states than at the national level. This is true across all three branches, most evidently in the legislative branch, where about onequarter of state legislators compared to under one-sixth of the members of Congress are women.

\section{Look on the Demand Side}

Consider first the institutional differences between the elected legislatures on one hand and on the other hand, the mostly appointed bureaucracies, such as the Senior Executive Service, the state agency heads, or the courts. This pattern of appointed compared to elected officials is long-standing. Since the 1980 s, when significant numbers of women came onto the field, their ranks have been skinnier in the legislatures than in the bureaucracies at both the national and state levels.

These differences between elected and appointed elites can be understood largely in terms of demand-side factors. Elite selection in the executive and judicial branches is by hierarchical choice, a decision focused in the single mind of a president or a governor. The choices voters make in selecting members of Congress or a state legislature partake more of market-like competition spread over a variety of constituencies. Furthermore, voters may be freer to discriminate in the privacy of the voting booth than are chief

Table 1 Women's progress by the twenty-first century

\begin{tabular}{llcc}
\hline & Executive $^{\mathrm{a}}$ & Judicial $^{\mathrm{b}}$ & Legislative $^{\mathrm{c}}$ \\
\hline Federal & $26.7 \%$ & $25.6 \%$ & $16.3 \%$ \\
States & $27-30 \%$ & $30.4 \%$ & $23.5 \%$ \\
\hline
\end{tabular}

${ }^{a}$ Senior Executive Service in 2005. Office of Personnel Management www.opm.gov/feddata/factbook2005/factbook2005.pdf. Accessed 2 September 2007. State Agency Heads in 2004. Kelleher et al. (2006) Table A ${ }^{\mathrm{b}}$ Supreme, Appellate \& District Courts in 2007. Federal Judicial Center. www.fjc.gov/history/home.nsf. Accessed 1 September 2007. Courts of last resort. National Center for State Courts, progers@ncsc. dni.us 13 February 2007.

${ }^{\mathrm{c}}$ Upper and lower houses combined. CAWP www.CAWP.rutgers.edu/ Facts.html. Accessed 1 September 2007. executives who will be held publicly accountable for getting the proportions closer to correct. The difference in representation ratios resulting from election or from appointment may be a matter of some voters and political operatives preferring women candidates less than men at the same time as governors and presidents are preferring women more.

One way to check out demand-side explanations for differences in women's representation in the stock of the governmental elite is to examine the flow into those positions. We can compare the speed of ascent, or the relative viscosity, for males and females entering appointed in contrast to elected positions in the early years of this century. Do women rise faster, or slower, or at the same rate as men? The data show that under appointment they rise faster, under election slower.

Between 2002 and 2007, over one-quarter of the 2,506 entrants to the Senior Executive Service were women. They were, on average, 2 years younger than their male classmates. This difference in rate of ascent to the Senior Executive Service parallels a faster promotion pace for women in the higher levels of the civil service at large. At the state level as well we find a slightly faster rise by women, as indicated by age at promotion for state agency heads in the 1990s and 2000s (Kelleher et al. 2006).

Women have been elevated to or through the ceiling in the federal courts at an earlier age than men from the time of Jimmy Carter on. The women that Carter elevated to the courts moved from law school to the bench on average about 5 years sooner than the men he nominated. Among George W. Bush's nominations, men took an average of 25 years after law school graduation to ascend while women did it in 22 .

The picture in the elected legislative branch reveals no similar degree of demand pressure. In fact, the pioneer women coming into Congress usually arrived at a more advanced age than the men there. To some extent, this age difference was a result of a significant number of them being drawn in as widows. Overall, it was a tougher struggle. By the millennium, however, elite recruitment had matured to the stage that women entering in the 106th through 110th Congresses (a decade that includes Democratic as well as Republican majorities), took, on average, less than a year more than their male classmates. The latest Center for American Women and Politics (2007, p. 4) report on the future of women state legislators finds, in contrast to what the Congressional Directory reports for federal legislators, an increase in the age at which women entered the legislative halls while men continue to join earlier in their careers. Though women are now getting a better shake, their rise still does not show the kind of demand effect that an age differential implies in the executive and judicial branches. 


\section{Look on the Supply Side}

What will a look on the supply side tell us about the causes of different viscosities in the flow of women into positions of power? This is mostly a pipeline issue, as suggested by the lag of progress at the federal level behind progress at the state level. In both the judicial and the legislative branches, the state level is a significant segment of the pipeline. In the federal judiciary, about one-third (a little less for males, a little more for females) of the currently sitting judges began their judicial careers at the state or local level. In recent years, about half of the women serving in the US Congress had come up through their state legislatures.

The importance of a supply-side perspective on women's progress in the legislative branch is underlined by the findings of systematic research at both state and national levels by Lawless and Fox (2005, pp. 19-26) - that women win elections at the same rate as do similarly situated men. The problem is not on the demand side, then, the problem is in bringing enough women into the electoral contest. How powerful is the state-to-nation pipeline for this purpose? Not very, it would seem, since the correlation across states of feminization in the 1990s with feminization in their congressional delegations 10 years later is a relatively weak +0.34 . But, let us examine the pipeline connection with a scatterplot in which states are arrayed horizontally in terms of the degree of feminization in their legislatures. Then we see an interesting pattern. Those states with $15 \%$ or less women in their legislatures in the 1990s were unlikely to have a significant representation of women in their congressional delegations in the subsequent decade, as shown in the vacant upper left quadrant of Fig. 1. At the same time, some states with strong representation at the state level fail to have any women at all in their congressional delegations. In other words, strength at the state level is a necessary but not a sufficient cause of strength at the national level.

\section{Percent Female in National $x$ Local Legislatures}

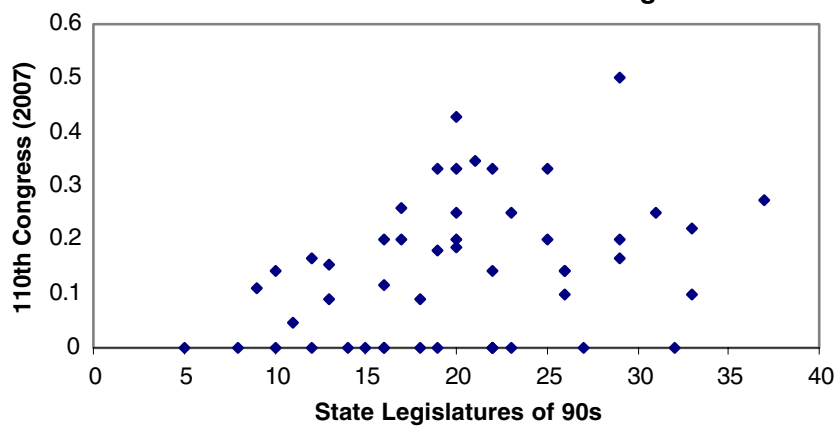

Fig. 1 States by percent female legislators. Sources: Kelleher et al. (2006); www.opm.gov/feddata/factbook2005/factbook2005/pdf. Accessed 2 September 2007
How fertile is the state source? If we look at the relationship over time, we can see a potential convergence of national and state level trends in female representation (Fig. 2). But this convergence seems to be based as much on fatigue in the feeder institutions as on vigor in the receiving institution. Although women have accelerated their entry into Congress over a 35-year span, with a noticeable jump in 1992, the "Year of the Woman," in state legislatures women's progress seems to be on the end of a sigmoid growth curve. This apparent plateau, at considerably below the $53 \%$ level, may be part of a more general phenomenon since it appeared also among statewide elective officials by several years ago. That plateau for state legislatures suggests a changed viscosity in electoral transit that may progress further along the pipeline to affect women's access to the national level. As noted by Lawless and Fox (2005. p.151), "Because state legislative office acts as a springboard to higher office, stagnation trickles up to the congressional level."

A fuller understanding of the supply-side prospects for raising the low representation of women in high places comes from looking further upstream, to the educational tributaries feeding the flow of talent. Many of the ascendants to top governmental office in the first years of this century were undergraduates in the later years of the last century, a time when the proportion of bachelor's degrees awarded to women was less than half. Now, the overwhelming majority of undergraduates are female.

A bachelor degree is not the only qualification for ascent. A majority of those who joined the Senior Executive Service or became state agency heads or entered Congress, and about half of those who entered state legislatures, had acquired a post-graduate degree, typically an MBA or a JD. Of course, almost all judges carried a JD into office. What do we know of the gender proportions in these higher-level talent streams? At those levels, in the early 1980s, female attainments were

Fig. 2 Women in the U.S. Congress and in state legislatures. Sources: www.cawp.rutgers.edu/ Facts.html Accessed 2 September 2007
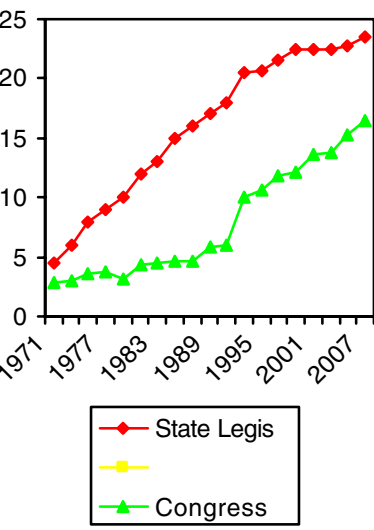
somewhat less - under $40 \%$ of the MBAs and a little over one-third of the law school graduates. In recent years, however, feminization of the general supply of the professionally educated class has grown apace. Threefifths of the enrollments in graduate degree programs are now women, as is true of those specially tailored for the public sector, the MPA and Public Affairs programs. Moreover, women rose to become half of law school enrollments by 2002, though there has been no further advance of the kind seen in the master's degrees in public affairs and public administration, and since arriving at parity there has been significant backsliding.

\section{Intractabilities?}

Speculation about future progress, given the multitude of factors operating on both the demand side and the supply side, can be perilous. Consequently, I will simply suggest a pair of possibly intractable elements on the supply side that may come into play as women approach parity. One is a gender difference in political ambition or temperament, which is the key to the caution that Lawless and Fox (2005) voiced in It Takes a Candidate: Why Women Don't Run for Office. How fixed we consider the future supply of temperament as a resource for the pursuit of public office depends on how firmly it rests in biology, a contentious topic about which Kingsley Browne (1995) has written extensively.

Yet, more contentious still is the question of talent. This is not a matter of whether males or females in general have more of a particular talent, such as verbal fluency or spatial perception. It is a matter of the distribution of a relevant talent at the extremes - the hypothesis of greater male variability that even the rigorously outraged National Academy of Sciences Panel (2006) could not reject out of hand as a plausible, partial explanation for the underrepresentation of women in top level science and engineering. This "idiot-genius" distribution is demonstrated in Fig. 3, where some 74 cognitive abilities tests given to national random samples of twelfth graders show boys and girls hitting the same mean, median, and mode. At the extremes, however, the bottom $10 \%$ of scorers includes five boys for every four girls, as does the top $10 \%$. This male variability finding is fairly well established for national random samples in the U.S. these days (Hedges and Nowell 1995) and it is a persistent finding, one which first hit the global scene in a study of all 11-year olds in Scotland way back in 1932 .

The fact of greater male variability is not just child's play. It shows up with young adults in the LSAT, where the female proportion scoring in the top tenth stagnated around $40 \%$ while their representation among test takers reached
Score Distributions:

High and Low Ends

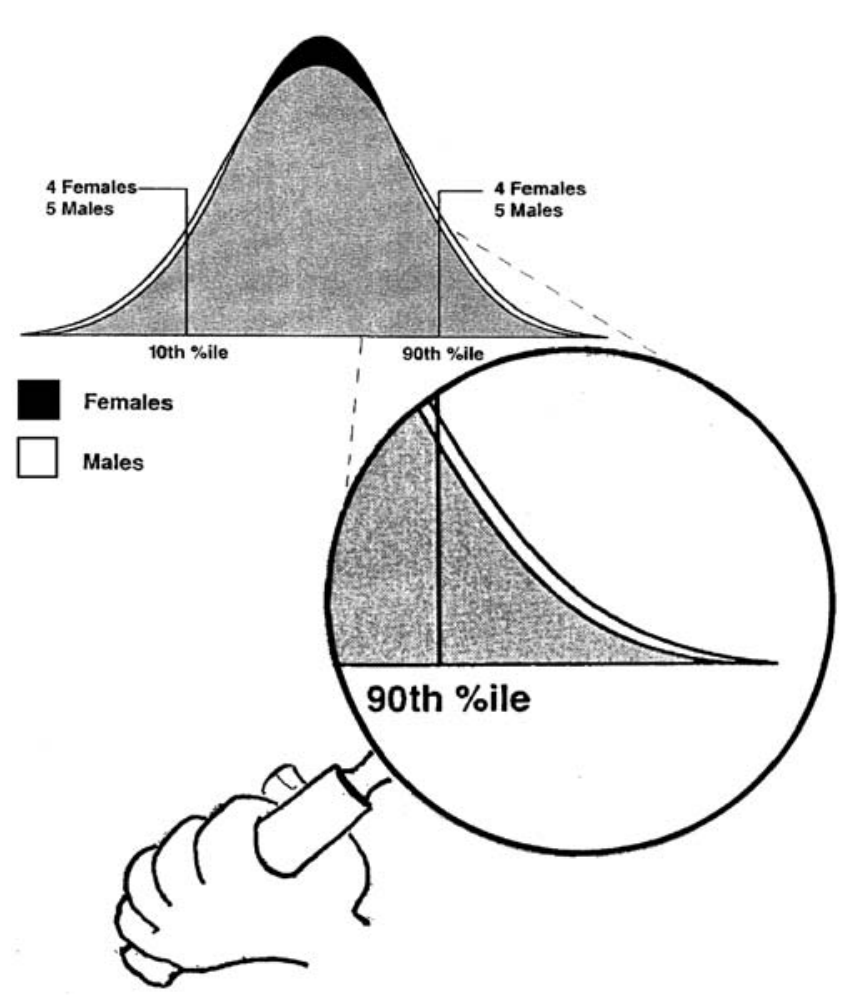

Fig. 3 Score distributions: high and low ends. Source: Adapted from Nancy S. Cole (May 1997) The ETS Gender Study: How Females and Males Perform in Academic Settings. Princeton: Educational Testing

toward $50 \%$. Its effects are also evident in the performance of men and women in law school itself, where women's performance in the top tenth in ten top law schools remained below $45 \%$ in the first five years of this century while the number of women in those law schools reached parity.

If elite selection for a governmental or other high-level office is shaped to some extent by such talents so distributed, the supply of qualified males will exceed the supply of qualified females by an increasing proportion the more highly selective the process is. For the top $10 \%$, the ratio is $5: 4$ as is shown in the magnifying glass of Fig. 3. For the top $5 \%$, the top $1 \%$, and so on, the ratio intensifies. 5:4, 4:3, $3: 2,2: 1,3: 1,4: 1 \ldots$ pretty soon, we get down to some of the female proportions shown back in Table 1. Keep in mind that the Senior Executive Service is highly selective, constituting about one-quarter of $1 \%$ of the General Schedule and Related Grades of the federal civil service.

Progress there will be, no doubt, but the pace may slow and the distance may fall short of parity is several places (Pinker 2008). Just as Herbert Simon noted that we must accommodate to bounded rationality in decision making, so must we confront a fenced utopia in the gender equity search. 
Open Access This article is distributed under the terms of the Creative Commons Attribution Noncommercial License which permits any noncommercial use, distribution, and reproduction in any medium, provided the original author(s) and source are credited.

\section{Further Reading}

Browne, K. R. 1995. Sex and temperament in modern society: a Darwinian view of the glass ceiling and the gender gap. Arizona Law Review, 37, 971-1106.

Center for American Women and Politics 2007. Women state legislators: Past, present and future. New Brunswick: Eagleton Institute of Politics, Rutgers University.

Cole, N. S. 1997. The ETS gender study: How females and males perform in academic settings. Princeton: Educational Testing Service.
Hedges, L. V., \& Nowell, A. 1995. Sex differences in mental test scores, variability, and numbers of high-scoring individuals. Science, 269, 41-45.

Kelleher, C. A., Bowling, C. J., Jones, J., \& Wright, D. S. 2006. Women in state governments: Gender representation in legislative, administrative, and other institutions of American society. In K. Chi (Ed.), Book of the States, 2006. Lexington: Council of State Governments.

Lawless, J. L., \& Fox, R. L. 2005. It takes a candidate: Why women don't run for office. New York: Cambridge University Press.

National Academy of Sciences 2006. Beyond bias and barriers: Fulfilling the potential of women in academic science and engineering. Washington DC: National Academies Press.

Pinker, S. 2008. The sexual paradox: Men, women and the real gender gap. New York: Scribner.

James F. Guyot is professor of Political Science in the Graduate School and of Public Affairs at Baruch College/CUNY. 